Geographical Dimensions of the Shining Path Insurgency in Peru

Author(s): Robert B. Kent

Source: Geographical Review, Oct., 1993, Vol. 83, No. 4 (Oct., 1993), pp. 441-454

Published by: Taylor \& Francis, Ltd.

Stable URL: https://www.jstor.org/stable/215825

JSTOR is a not-for-profit service that helps scholars, researchers, and students discover, use, and build upon a wide range of content in a trusted digital archive. We use information technology and tools to increase productivity and facilitate new forms of scholarship. For more information about JSTOR, please contact support@jstor.org.

Your use of the JSTOR archive indicates your acceptance of the Terms \& Conditions of Use, available at https://about.jstor.org/terms 


\title{
GEOGRAPHICAL DIMENSIONS OF THE SHINING PATH INSURGENCY IN PERU*
}

\author{
ROBERT B. KENT
}

\begin{abstract}
The Shining Path insurgency began in Peru in 1980. The strategy emphasized rural revolution, establishment of liberated zones, and encirclement of cities. The counterinsurgent campaign in 1983 prevented the creation of a permanent territorial base in the departments of Ayacucho and Apurimac but led to expansion of insurgent operations northward in the central Andes. In the mid-1980s the insurgents advanced into the rain-forest region of the upper Huallaga Valley and onto the altiplano in the southern Andes. Lima and its surrounding shantytowns were included in insurgent activities by the late 1980s. The insurgents displayed an uncanny ability to maintain their struggle over a vast area and in different natural and social environments.
\end{abstract}

$\mathrm{T}^{\mathrm{H}}$

HE effective control of geographically based regions leading to the establishment of an insurgent state is an axiom of modern revolutionary movements. The creation of an insurgent state may be conceptualized as a three-stage military-political process, with each stage characterized by distinct territorial expressions (McColl 1969, 614; 1975, 303). The first stage, mobile warfare, is typified by the ephemeral nature of insurgent activities and the insurgents' tentative confrontation of state power. At this stage the insurgents have no fixed base or permanent territorial presence. Guerrilla warfare, the second stage, is marked by the insurgents' increasing ability to confront the state openly and by establishment of a core area which they control. In the later phases of this stage, additional insurgent core areas controlled by insurgents are established. The final stage is the creation of a full-fledged, territorial-based insurgent state. This stage is characterized militarily by the insurgents' ability to compete openly with the forces of the established state and administratively by imposing territorial units and structures of governance.

In 1980 a Maoist faction of the Communist party in Peru, known as the Sendero Luminoso, or Shining Path, initiated an armed insurgency against the Peruvian state. The effects of the Shining Path on the economic, social, and political life of Peru have been widespread. The strategy and tactics of the Shining Path have included important geographical elements in the movement's efforts to overthrow the successive democratic governments. This article identifies the territorial dimensions of the Shining Path insurgency and analyzes its progress toward the establishment of an insurgent state.

* A faculty research grant from the Graduate School of the University of Akron partially funded this research.

- DR. KENT is an associate professor of geography and planning at the University of Akron, Akron, Ohio 44325.

Copyright (C) 1993 by the American Geographical Society of New York 
Beginning in the mid-1960s the Shining Path established a vast network of supporters and sympathizers in the rural areas of the southern Andean departments of Ayacucho and Apurimac, primarily through control of the education faculty at the Universidad Nacional San Cristóbal de Huamanga in Ayacucho (Degregori 1990). Control of faculty and curriculum provided adherents of the Shining Path with a mechanism for recruiting revolutionary cadres from the population of provincial youths who accounted for the majority of the students at the university. Many of those early revolutionary cadres completed their studies and became school teachers in the district capitals and hamlets of Ayacucho and Apurimac. They provided the Shining Path with invaluable opportunities, including the use of teaching positions to diffuse its revolutionary message, the establishment of a widespread network of adherents and sympathizers in the countryside, and the geographical basis for the creation of territorial strongholds and eventually of so-called liberated zones once the armed struggle was initiated.

\section{The Regional CORE}

During the late 1970s the Shining Path left the university in Ayacucho and relocated to relatively inaccessible areas of the countryside, where it created "popular schools," worked closely with peasants, and began forcibly to disperse the representatives of the state, local capitalists, and large landowners (Gorriti Ellenbogen 1990, 86). Several provinces in northern Ayacucho and the province of Andahuaylas in neighboring Apurimac formed the principal territorial focus of these activities (Fig. 1).

Securely established in these areas, the Shining Path initiated its armed conflict in Ayacucho in 1980. It followed a Maoist model that called for liberation of the countryside, an end to market-oriented agricultural production, and disarticulation of the capitalistic marketing system. Theoretically those policies would eventually cut off the supply of basic food commodities to cities, increase urban social disorder, and allow the Shining Path to encircle the principal urban areas, culminating in the downfall of the Peruvian state.

The Shining Path pursued its three-stage strategy successfully during the early 1980s in Ayacucho and Apurímac. Several operational and guerrilla zones were established when armed attacks on police outposts and stations led police officials to abandon large areas of rural Ayacucho. Threats, intimidations, and selective assassinations encouraged the retreat of the representatives of the central government, as well as of elected local officials and other community leaders. In several instances the result was the creation of full-fledged support bases, in which the Shining Path established its own governance structures to replace those of the central government and local indigenous institutions.

The isolated upper reaches of the Caracha River, some twenty kilometers southwest of Cangallo in Ayacucho, is one such area. The center of a small farming and grazing region lying between 3,000 and 4,000 meters, it includes 


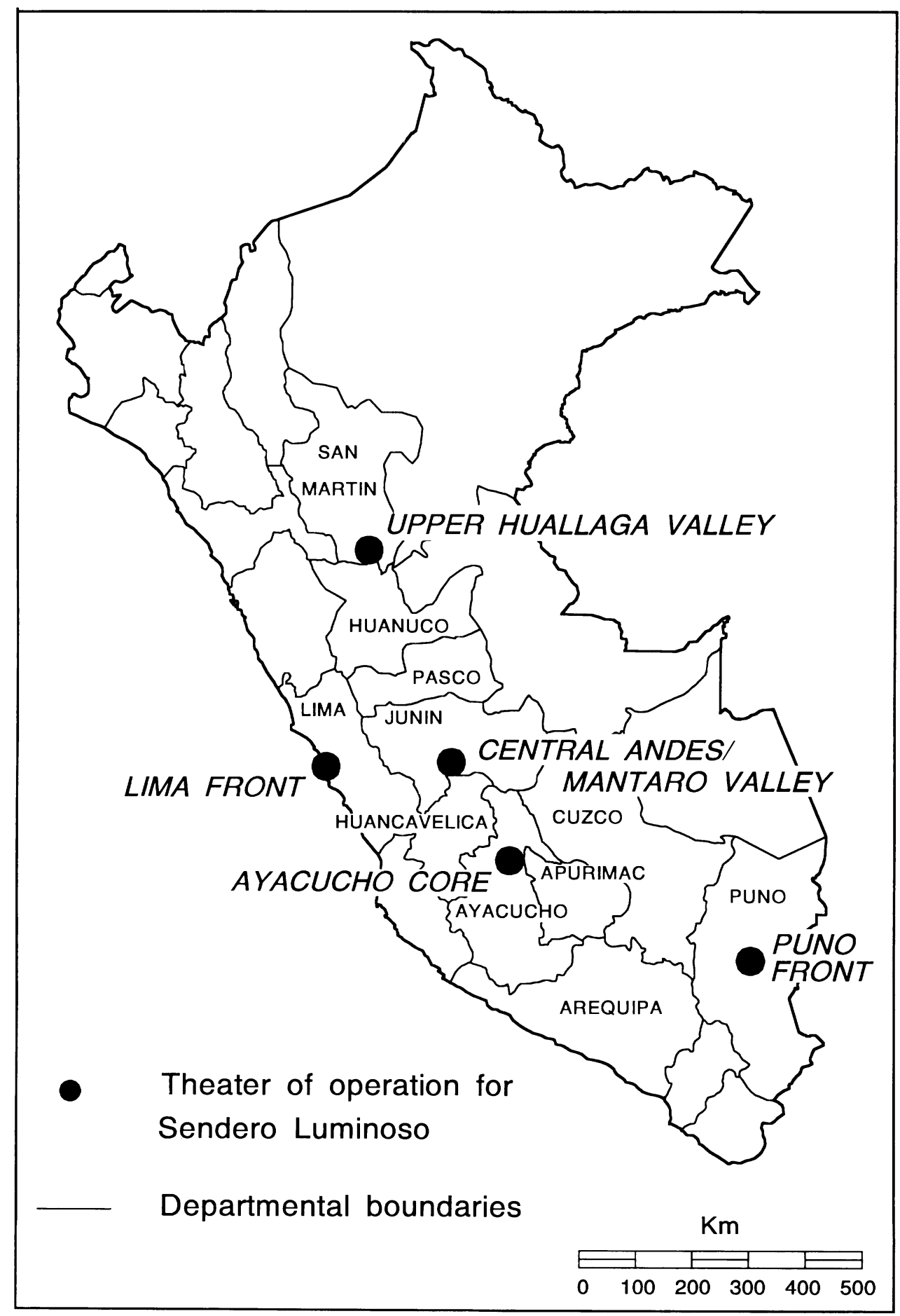

FIG. 1-Areas of Shining Path activity in Peru. 
the towns of Lucanamarca, Carapo, Sacsamarca, and Huanca Sancos. In late 1981 the Shining Path began to operate openly there, convening town meetings in the central square of Huanca Sancos and haranguing local residents with revolutionary messages (Bonner 1988, 42). The Shining Path rapidly took control of the town, using the municipal building for its offices and living quarters. The local Shining Path chief was a high-school teacher who had been living in the town for four years.

The social and economic life of the townspeople was rapidly reordered. Travel into and out of town was controlled by Shining Path guards; public meetings were banned except when villagers were to receive revolutionary doctrine from the cadres; and economic life was modified radically. Villagers were prohibited from owning more than five head of cattle and fifty sheep. Farmers were ordered to reduce field output and to produce only enough for their subsistence needs (Gorriti Ellenbogen 1990, 375). Food became scarce, and many villagers were reportedly reduced to eating one meal a day (Bonner $1988,42)$. The execution of a respected former teacher and mayor further alienated the populace.

In early 1983, after more than a year of rule by the Shining Path, local discontent led to bloody confrontations between the populace and insurgents in Sacsamarca, Huanca Sancos, and Lucanamarca. Those confrontations resulted in the death of about sixty peasants in Lucanamarca and perhaps as many as eighty Shining Path fighters at the hands of villagers from Sacsamarca who were assisted by a handful of police (Bonner 1988, 45-46).

Nearby, along the upper reaches of the Pampas River, into which the Caracha flows, a similar pattern of territorial occupation and incipient Shining Path rule evolved. By mid-1981 the Shining Path had begun the first phase of territorial domination in the village of Chuschi with a moralization campaign, a technique, subsequently used in other areas, which singles out thieves, abusive governmental officials, and local elites for punishment and is usually met with widespread popular support (Berg 1986/87, 170; Manrique 1990/91, 33; Smith 1992b, 25). By December 1981 the Shining Path had closed the municipality and named a "popular committee" to govern local affairs (Isbell 1992, 66).

The Shining Path mandated a drastic reorganization of social and economic life in Chuschi (Isbell 1992, 66). Key elements included attempts to outlaw fiestas and drinking, abolition of the traditional civil-religious system of governance, imposition of a communal planting system based on residential neighborhoods, prohibition of peasant participation in the weekly markets, and an attempt to close the only road to the town. However, the Shining Path was resisted on all counts, and its efforts to implement the changes had generally failed by late 1982 .

During that year the Shining Path controlled not only Chuschi but also many other small towns and villages in the upper Pampas and farther down the valley (Isbell 1992, 67). At the same time, in the rural areas of the adjoining 
province of Andahuaylas, local authorities resigned their offices. The Shining Path held sway over most of the rural areas but apparently did not establish new local-government structures under its control (Berg 1986/87, 180).

By the end of 1982, when the Shining Path's rule was unraveling in the upper reaches of the Caracha and Pampas rivers, the central government realized that the police forces were unwilling or unable to confront the threat posed by the movement. Evidence suggests that police authorities allowed systematic abandonment of posts in many towns, often despite the protests of local residents (Gorriti Ellenbogen 1990, 86, 305, 332). President Fernando Belaúnde militarized the conflict by dispatching army and marine units to Ayacucho. An aggressive, violent counterinsurgency campaign began there early in 1983. Along with egregious violations of human rights (Americas Watch 1990; Amnesty International 1991), the military successfully prevented the Shining Path from establishing permanent liberated areas or support areas but did not succeed in eliminating the movement from the region.

In Andahuaylas, along the eastern margin of the Pampas River, the government's counterinsurgency campaign drove the Shining Path from the most accessible rural areas. Many of its cadres retreated to remote, relatively inaccessible villages like San Antonio de Cachi and Cocharcas, where they appointed popular committees between 1983 and 1985. San Antonio de Cachi, for example, remained firmly under Shining Path control and served as a permanent support base for its regional activities (Gonzalez 1988, 52). However, the most experienced and best-trained cadres were transferred elsewhere to open new fronts. Thus, although the repression by the central government checked expansion of the movement in Ayacucho and Andahuaylas, it encouraged geographical dispersal and intensification of the insurgency elsewhere.

The Shining Path remains a strong presence in Ayacucho and Andahuaylas, operating with relative freedom in the rural areas and attacking at will small towns and peasant communities that oppose it. It regularly ambushes bus and truck traffic along the main roads and is capable of cutting access to the departmental capital of Ayacucho for short periods (Brooke 1992b, A3). This strength results not from a social compact with peasants and workers but from the movement's evolution into an efficient, mobile guerrilla force that uses threats, violence, and terrorism to intimidate the local populace (DESCO 1989, 345).

\section{A WIDENING INSURRECTION}

Although the Shining Path concentrated its territorial energy on Ayacucho and Apurimac during the early 1980s, by mid-decade it was active throughout Peru, and nearly every department registered some violence attributable to the movement. The department of Lima, especially metropolitan Lima, represented a secondary focus of Shining Path activity, and many violent incidents were reported there between 1980 and 1984. This 
department ranked second only to Ayacucho and actually surpassed it in 1981 (DESCO 1989, 28).

As the government pursued its counterinsurgency campaign in Ayacucho and Apurimac in 1983 and 1984, the Shining Path extended its geographical reach. The growth in the number of provinces affected by the central government's declarations of a state of emergency between 1985 and 1989 illustrates the expanding territorial coverage of the insurgency (Fig. 2). The Shining Path directed its efforts into three new theaters of operation-north into the central Andean departments of Huancavelica, Junín, Pasco, and Huánuco; northeast into the tropical rain forests of the upper Huallaga Valley; and south into the department of Puno on the altiplano.

\section{The Central ANDES}

The dispersal of the Shining Path northward along the Andean axis was due in part to its understanding of the Andean ecosystem and its ability to exploit it tactically. The Shining Path's preferred field of operations in the Andes has been the ecological zone known as the puna, land that is generally above 4,000 meters. This zone stretches nearly uninterrupted along most of Peru's Andean axis. It is sparsely populated, remote, and inaccessible to governmental forces, which usually are garrisoned in towns and cities along the valley floors and concentrate their activities in adjacent areas. Besides offering a remote refuge and a transportation axis, the puna provides commanding access to most of the populated regions below it (Smith 1992b, 17).

A main thrust by the Shining Path northward was into Junin, specifically the Mantaro Valley, which lies almost directly east of Lima. This valley has great strategic importance. It is a leading producer of foodstuffs for Lima, the focus of many mining enterprises in the mountains surrounding the valley, a key provider of hydroelectric power to Lima and other parts of Peru, and an important crossroads for highways that run north-south along the Andean chain and east-west from Lima to the tropical rain forests on the eastern front of the Andes (Manrique 1989, 63-64). The Shining Path did not encounter ideal conditions for the spread of its revolutionary model in the Mantaro Valley. Most peasant communities there are sophisticated, are integrated into the national economy, experience some economic success, and have a strong tradition of independence.

As a result, the Shining Path has had mixed results. Peasant farmers and livestock producers on or adjacent to the valley floor have generally opposed its presence and have been outraged by its actions. The destruction of the only milk-processing plant in the valley had devastating effects on members of the producers' cooperative that depended on the plant. The action led many members to take up arms and confront the movement (Manrique 1989, 64). Some communities, like Ingenio, situated on the eastern margin of the valley, have resisted Shining Path intrusions by establishing communitydefense patrols, often at the urging or under the aegis of the government's 


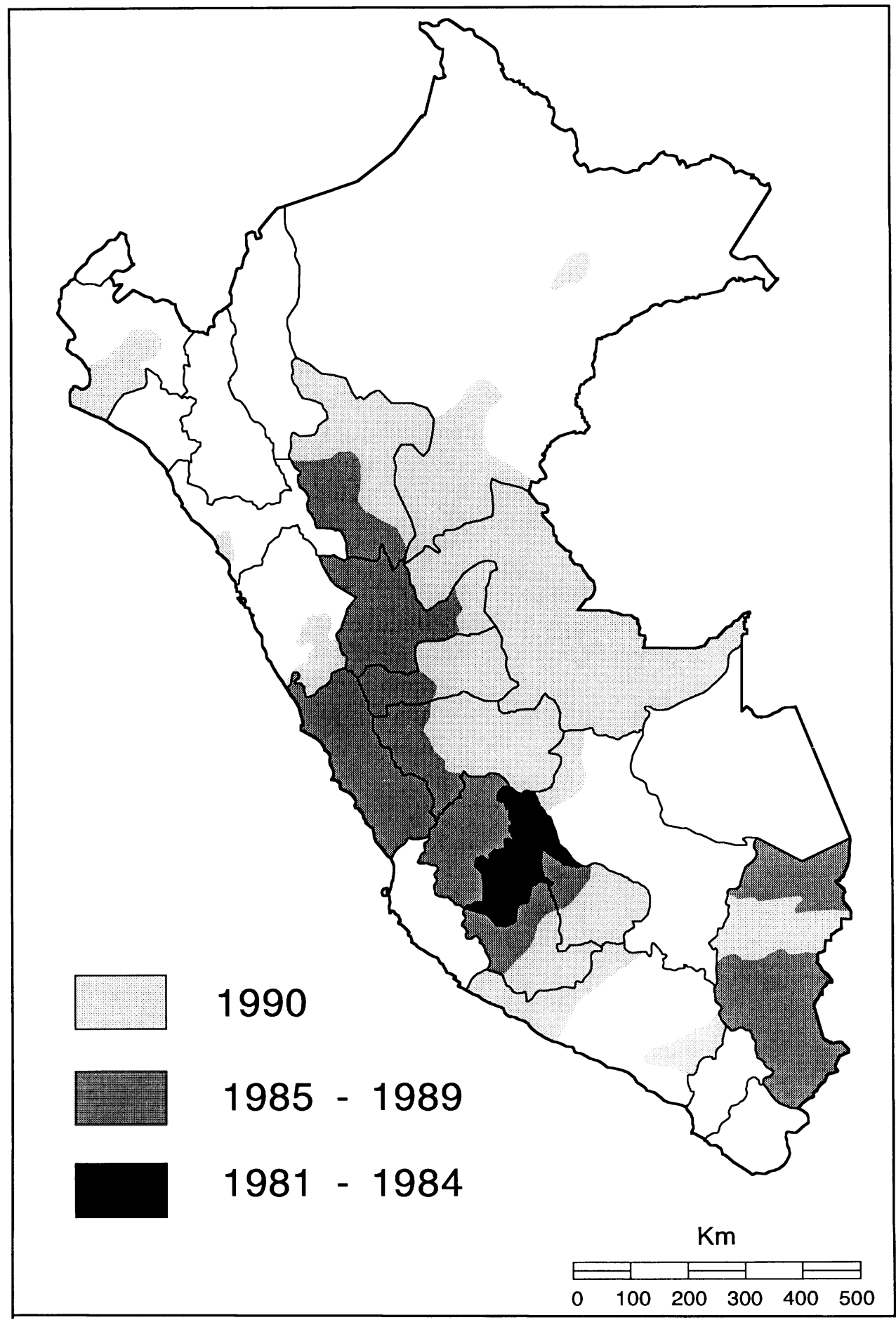

FIG. 2-Areas of Peru under a state of emergency 1981-1990. Shading indicates first date on area was placed under a state of emergency. Source: Peru 1991. 
military forces (Brooke 1992a, A4). The presence of the Shining Path in the Mantaro Valley has also been contested by another armed revolutionary group, the Movimiento Revolucionario Tupac Amarú (MRTA).

Nevertheless, the Shining Path has had some success in the Mantaro Valley, especially in the upland areas of livestock grazing that surround the valley. From late 1988 to at least mid-1989, the Shining Path established a liberated zone in the Canipaco Valley, in the southeastern corner of the Mantaro Valley, about thirty kilometers south of the city of Huancayo. Livestock raising is the principal economic activity in this small valley, and when the Shining Path arrived in the region, it demanded that an agricultural cooperative, the SAIS Cahuide, be dissolved, which it was (Manrique 1990/ 91, 33). As it did elsewhere, the Shining Path initiated a moralization campaign, in which it executed several cattle thieves and ordered local merchants to treat peasants fairly. Later it executed twelve village leaders for defiance and ordered peasant cultivators to produce only enough to be self-sufficient. The destruction of the SAIS Cahuide was similar to Shining Path treatment of other economic enterprises in upland grazing areas of the valley (Manrique 1989, 66).

Even there Shining Path success was limited. At the northern end of the valley, in the provinces of Jauja and Yauli, three cooperatives, the SAIS Tupac Amarú, Pachacútec, and Ramón Castilla, continue to operate and prosper despite violent attacks on their installations and personnel by the Shining Path (Sánchez Enríquez 1989, 86). Their survival seems to have resulted from several factors. Perhaps the most significant is that the members of those cooperatives immediately recognized the grave threat that the Shining Path posed to their survival, and they took action. Their economic solvency was a key factor in their ability to respond effectively to Shining Path threats. In contrast with the SAIS Cahuide, which had been declining since its founding in 1971, the other cooperatives were wealthy enough to invest in security arrangements for their installations and personnel when the Shining Path incursions occurred in 1987 (Sánchez Enríquez 1989, 94-96).

The assertion in a popular book on the Shining Path (Strong 1992, 197) that its flag now flies over hundreds of villages in Junín is clearly an exaggeration. The department has barely one hundred places that might be described as villages (Kent and Sandoval Ricci 1984). Nevertheless, Junín is one of the most violent and actively contested regions in Peru: the more than ninety incidents of revolutionary violence there in 1991 made it the second most violent department, after Lima (Instituto de Defensa Legal 1992, 29, 273).

\section{The Upper Huallaga Valley}

The second main thrust of the Shining Path was into the tropical rainforest region on the Andean piedmont in the upper Huallaga Valley, which lies in the center of the department of San Martín and extends upslope into 
the neighboring department of Huánuco. The upper Huallaga Valley is one of the principal coca-producing regions in Latin America-indeed, the world. Somewhere between 50,000 and 100,000 hectares of coca were being cultivated there during the late 1980s. Nearly all of the region's 170,000 inhabitants were directly or indirectly involved with drug trafficking. The annual value of coca production in the valley was estimated at U.S. \$550 million in the late 1980s (Laity 1989, 1-7).

The upper Huallaga Valley offered the Shining Path new opportunities and challenges. A regional economy dependent on an illegal export crop represented a tremendous chance for shrewd exploitation. The activities associated with crop production and with drug processing and marketing were divided among three groups: coca-growing peasant farmers; drug traffickers, who were often Colombians; and the national police and its sometime-allies, the Peruvian military and the U.S. Drug Enforcement Agency (González 1989, 22-24).

The Shining Path successfully inserted itself into this situation by entering into a patron-client relationship with the peasant coca growers. It was able to defend the interests of peasants by severely reducing the effectiveness of the government's coca-eradication programs, by eliminating corrupt elements of the police and army that exploited peasant farmers and processors, by raising prices paid to peasant cultivators by Colombian buyers and traffickers, and by charging traffickers substantial sums in landing fees and for safe passage. First and foremost, this arrangement has provided the Shining Path with a comparatively solid territorial base of operations and a natural clientele as long as the central government maintains a policy of curtailing coca production. In addition, the ready contact with drug traffickers has given the Shining Path access to sophisticated weaponry-for a price. Finally, activities in the upper Huallaga Valley are a source of hard currency for the Shining Path, which is estimated at between U.S. \$20 million and $\$ 100$ million annually (McCormick 1990, 22; Gonzales 1992, 121).

Some observers suggest that the Shining Path moved into the upper Huallaga Valley as early as 1980 in Aucayacu (Huánuco) and Puerto Pizana (San Martín) (Gonzales 1992, 106). The insurgents' military opening of this front began sometime in late 1983 or early 1984 and was so intense by mid1984 that the government placed the provinces under a state of emergency in July 1984 (Tarazona-Sevillano 1990, 70-71; Gonzales 1992, 107; Strong 1992, 110). Initially the military checked and even reduced the power of the Shining Path in the area through a combination of good counterinsurgency and astute political tactics. The insurgents were pursued aggressively, and control of escape routes into the mountains severely restricted their military operations. Local military commanders clearly stated that the military action was against the Shining Path, not coca-growing peasants or traffickers. The military were able to undercut severely local support for the insurgents (Gonzales 1992, 107). 
The persisting efforts by the Shining Path to maintain and expand its presence in the upper Huallaga Valley, the continuing importance of the drug trade in the regional economy, and a change to less aggressive and less enlightened military leadership in the region significantly eroded governmental control in subsequent years. In early 1987 attacks by the Shining Path in the upper Huallaga Valley began again in earnest (Gonzales 1992, 108).

By mid-1988 the Shining Path effectively controlled an area of the valley almost one hundred kilometers long, from Paraíso on the north to Aucayacu on the south (Contreras 1989, 44; Gonzales 1992, 109-111). Popular committees were established to run local affairs, and popular schools were also instituted. Both received broad civilian acceptance, but true ideological support was limited. Most local support came from a desire to protect the coca economy (Gonzales 1992, 111). By late 1988 the Shining Path controlled the main road through the valley and even charged tolls at some points.

The hold of the Shining Path on the upper Huallaga Valley is not secure. Its actual territorial control is tentative and frequently contested. Armed confrontations and political violence occur regularly (Instituto de Defensa Legal 1992, 283-287). In the early 1990s the MRTA was also a force to be reckoned with. The Shining Path drove the MRTA from the upper reaches of the valley, but both groups contested its central portions. The MRTA alone challenged the government along the lower course of the Huallaga River (Instituto de Defensa Legal 1992, 283). By mid-1993 the MRTA's operational capacity was almost destroyed.

\section{THE SOUTHERN FRONT}

The Shining Path began operations in the southern Andes on the altiplano of Puno in late 1981 (Taylor 1987,143). Its early efforts to establish a presence in Puno are attributable to four factors: the attractiveness of its northern subtropical province, Carabaya, as a refuge for the guerrillas who were under significant pressure in Ayacucho; a desire to open a new theater of operations, which would cause military forces to be spread more thinly; the ready accessibility to the Bolivian frontier, from which supplies might be smuggled; and the long-term goal of disrupting economic activity in the hinterland of Arequipa, the second-largest city in Peru, in which the department of Puno plays a crucial role (Taylor 1987, 143).

The early activities of the Shining Path focused on covert political organizing, especially in the provinces of Azángaro and Melgar (Taylor 1987, 143). Soon it started military actions, and armed columns penetrated Puno by crossing the puna from Ayacucho and Apurimac. Again many of its initial actions focused on a moralization campaign. It enjoyed some early successes, establishing support bases and even some military training bases (Instituto de Defensa Legal 1989, 14). By 1985 armed violence against local officials and politicians had begun.

In Puno the Shining Path encountered a social and political environment considerably different from that in Ayacucho. The sophisticated and pro- 
gressive peasantry have many large organizations with a strong rural presence. Nongovernmental organizations with a record of concrete actions, a progressive Roman Catholic Church leadership with strong ties to peasant communities and organizations, and viable, well-organized political parties and coalitions on the left function in the region (Instituto de Defensa Legal $1989,3)$. These groups occupied the political and social space that the Shining Path sought.

In other respects, Puno seemed ripe for the Shining Path revolutionary message. For years peasant organizations, dissatisfied with the rural agricultural enterprises established as part of the military government's agrarian reform program, had agitated for the breakup of the agricultural cooperatives and of the large estates that were still privately owned.

The Shining Path inserted itself into the continuing effort at land reform led by the departmental peasant federation with support from leftist political parties and the Roman Catholic Church (Taylor 1987, 144; Instituto de Defensa Legal 1989, 16). As discontent grew in 1985 and 1986, land invasions led by peasant organizations occurred with some regularity, and armed Shining Path fighters sometimes appeared as uninvited participants professing solidarity with the peasants. The Shining Path also attacked rural enterprises in Puno, destroying buildings and machinery, distributing livestock to local residents, and often killing estate managers and personnel (Taylor 1987, 144). Even peasant communities were subjected to Shining Path economic equality, when the livestock of wealthier peasants were given to their poorer brethren.

Shining Path tactics and methodology were rejected by peasants, peasant organizations, and the political left in Puno. Thus in 1987 the Shining Path launched a frontal attack on peasant organizations and their leaders, on party militants and leaders of the left, and on Roman Catholic Church activists (Instituto de Defensa Legal 1989, 17-18). Its execution squads murdered town, district, and provincial officials (Instituto de Defensa Legal 1989, 18; Rosenberg 1991, 207). In 1989 its arsonists destroyed the Institute for Rural Education, operated in Ayaviri by a Roman Catholic order (Klaiber 1992, 37). Using violence backed by the threat of death, the Shining Path sought to create power vacuums that it would fill. It did limit political participation in some areas. For example, by July 1989 seven of the eighteen districts in Azángaro had no local authorities because they either had been assassinated or had resigned (Instituto de Defensa Legal 1989, 18). Recent reports from Azángaro suggest that the Shining Path remains very active and may have made advances in infiltrating and controlling some local peasant organizations (Brooke 1993, A3).

\section{THE SHANTYTOWNS OF LiMA}

The Shining Path refocused its strategy from rural to urban areas, specifically Lima, in the late 1980s (McCormick 1992). By 1991 more than half of all incidents of political violence occurred in Lima and the neighboring 
port city of Callao (Instituto de Defensa Legal 1989, 29). The focus on Lima may have resulted from the failure of the Shining Path to establish extensive liberated zones in the countryside and from the relative success of the military in combating the rural insurgency (Smith 1992a, 127). The shantytowns of Lima offered better protection from the security forces and more fertile ground for recruiting activities than did rural areas. Ironically, many peasants who had fled the violence of Shining Path cadres and counterinsurgency forces in rural areas of Ayacucho found themselves facing the same threats in Lima (Kirk 1991, 14). Oddly, the early Shining Path strategy of encircling the city from the countryside may actually be replicated in its current focus on firm bases of support in the shantytowns that encircle Lima.

The Shining Path has concentrated on establishing a presence in the shantytowns along the Central Highway between Lima and the agricultural and mining centers of the Mantaro Valley. The area has additional strategic value because a significant proportion of the industrial capacity of Lima is located there and because key water and electrical transmission lines that supply Lima parallel the highway from the highlands (Smith 1992a, 128).

Huaycán, one such shantytown, represents one of the earliest and best documented efforts by the Shining Path to establish a dominant presence in the area. Established in 1984, the settlement grew rapidly; by the following year it had a population of some 22,000. Realizing the strategic opportunities of the settlement's location and impoverished inhabitants, the Shining Path moved as many as one hundred of its partisans into the community (Smith 1992a, 137). The Shining Path exploited the situation but failed to gain widespread or even significant support among the local residents. Some observers suggest that it failed because the population was simply too large and because the Shining Path did not offer evidence that it could govern to the benefit of the community (DESCO 1991, 30-31). Between 1988 and 1989 it shifted most of its activities out of Huaycán. Nevertheless, its presence is still felt, and its efforts to intimidate local leaders and community organizers continue (Nash 1992, A6).

After its retreat from Huaycán, the Shining Path used a new tactic to gain control of areas adjacent to the Central Highway. Instead of attempting to infiltrate and then dominate an existent shantytown, the Shining Path organized a new settlement. In July 1990 some 300 individuals under the direction of the Shining Path invaded a fifteen-hectare parcel adjacent to the Central Highway (DESCO 1991, 31). The parcel was enclosed with a twelvefoot-high adobe wall; guard towers were built at each corner of the square enclosure; and only two entrances were constructed. New settlers were quickly absorbed, and the population reached 1,500 within a few months. The Shining Path strictly controlled the social life of the settlement. The entrances were guarded at all times; no strangers were permitted inside; and all visitors were registered and accompanied during their stay. Residents participated in political indoctrination sessions, communal work parties, community garden projects, military exercises, and collective meals (DESCO 1991, 32). 
Within a year Shining Path control of the small settlement was too much for the government to ignore. When the lawsuit against the land invasion favored the legal owners, the Shining Path pressured local governmental officials to oppose the decision. It also blocked the Central Highway, which on two occasions resulted in violent confrontations with the police and the military, to force resolution of the issue in its favor. The property owner requested that the eviction order be rescinded and that a peaceful settlement be reached with the residents. It seemed like a Shining Path victory.

Less than a month later, military forces surrounded the compound, and armed confrontation seemed inevitable. However, the military began a civicaction campaign of peacefully distributing food and medicine and mixing with the settlement's residents. The Shining Path activists were caught off guard; no violent confrontation ensued; and the influence of the Shining Path over the settlement waned but did not disappear. Perhaps most significantly, the experience provided the Shining Path with a working model of how to dominate other shantytowns in the future (DESCO 1991, 34).

By mid-1992 the Shining Path had established a strong presence in at least seven areas of Lima-Callao, primarily in shantytowns (Los miradores 1992, 34-35). Some of these strongholds are strategically located along or near major transportation routes and facilities, most importantly the Pan-American Highway, the Central Highway, and the international airport. Several areas are on small, heavily urbanized hills. Entry into these areas is restricted to a few access points that the Shining Path can control, so they serve as refuges and observation posts over parts of the metropolitan area.

\section{CONCLUSIONS}

The territorial evolution of the Shining Path generally conforms to the three-stage pattern of other modern insurgency movements. The Shining Path shifted from a mobile presence to areas in which it established administrative structures, but effective governmental response prevented designation of a permanent territorial core. The Shining Path opened new theaters of operations, where the first two stages were repeated. The most successful has been in the upper Huallaga Valley, the main coca-growing region in Peru. Here the Shining Path both controls and administers the territory. Nevertheless, the Shining Path is far short of realizing the third stage of a successful revolutionary movement. Control of the valley area may offer the Shining Path its best prospects for an insurgent state, but that scenario is not imminent.

\section{REFERENCES}

Americas Watch. 1990. In desperate straits: human rights in Peru after a decade of democracy and insurgency. New York: Americas Watch.

Amnesty International. 1991. Peru: human rights in a climate of terror. New York: Amnesty International USA.

Berg, R. H. 1986/87. Sendero Luminoso and the peasantry of Andahuaylas. Journal of Inter-American Studies and World Affairs 28(4):165-196.

Bonner, R. 1988. A reporter at large: Peru's war. The New Yorker 4 January:31-37, 40-42, 45-58. 
Brooke, J. 1992a. A roadblock to the Shining Path: peasants forming defense communities. New York Times 26 May.

- 1992b. Where Shining Path took root, the seed of hope. New York Times 17 September. 1993. The rebels lose leaders, but give Peru no peace. New York Times 5 February.

Contreras, J. 1989. With the Shining Path. Newsweek 24 April.

Degregori, C. I. 1990. El surgimiento de Sendero Luminoso: Ayacucho 1969-1979. Lima: Instituto de Estudios Peruanos.

DESCO. 1989. Violencia política en el Perú, Tomo I. Lima: DESCO Centro de Estudios y Promoción del Desarrollo.

- 1991. El gran ensayo de Raucana. Quehacer 73:30-34.

Gonzales, J. E. 1992. Guerrillas and coca in the upper Huallaga Valley. The Shining Path of Peru, ed. D. S. Palmer, 105-126. New York: St. Martin's Press.

Gonzalez, R. 1988. Sendero: los problemas del campo y de la ciudad ... y además el MRTA. Quehacer 50:46-62.

- 1989. Coca's Shining Path. NACLA Report on the Americas 22(6):22-24.

Gorriti Ellenbogen, G. 1990. Sendero: historia de la guerra milenaria en el Perú. Lima: Editorial Apoyo.

Instituto de Defensa Legal. 1989. Puno hoy: tierra y violencia. Lima. . 1992. Peru hoy: en el oscuro sendero de la guerra. Lima.

Isbell, B. J. 1992. Shining Path and peasant responses in rural Ayacucho. The Shining Path of Peru, ed. D. S. Palmer, 59-82. New York: St. Martin's Press.

Kent, R. B., and A. Sandoval Ricci. 1984. Evolución de servicios públicos distritales en la Sierra Central del Perú. Revista Geográfica (Mexico City) 99:35-55.

Kirk, R. 1991. The decade of Chaqwa: Peru's internal refugees. Washington D.C.: U.S. Committee on Refugees.

Klaiber, J. 1992. Peru: the church and the Shining Path. America 166(6):136-138.

Laity, J. 1989. The coca economy of the upper Huallaga Valley. USAID document ID 3979P (typed), Washington, D.C.

Manrique, N. 1989. Sierra central: la batalla decisiva. Quehacer 60:63-71. 1990/91. Time of fear. NACLA Report on the Americas 24(4):28-38.

McColl, R. W. 1969. The insurgent state: territorial bases of revolution. Annals, Association of American Geographers 59:613-631.

- 1975. Geopolitical themes in contemporary Asian revolutions. Geographical Review 65:301310.

McCormick, G. H. 1990. The Shining Path and the future of Peru. R-3781-DOS/OSD. Santa Monica, Calif.: RAND Corp.

. 1992. From the Sierra to the cities: the urban campaign of the Shining Path. R-4150-USDP. Santa Monica, Calif.: RAND Corp.

Los miradores de Sendero: la batalla de Lima. Caretas 16 March:34-39.

Nash, N. C. 1992. Shining Path still stalks Lima's shanties. New York Times 16 September.

Peru. Senado de la República. 1991. Comisión especial de investigación y estudio sobre la violencia y alternativas de pacificación. Lima.

Rosenberg, T. 1991. Children of Cain: violence and the violent in Latin America. New York: Morrow.

Sánchez Enriquez, R. 1989. Las SAIS de Junín y la alternativa comunal. Debate Agrario 7:85-101.

Smith, M. L. 1992a. Shining Path's urban strategy: Ate Vitarte. The Shining Path of Peru, ed. D. S. Palmer, 127-148. New York: St. Martin's Press.

1992b. Taking the high ground: Shining Path and the Andes. The Shining Path of Peru, ed. D. S. Palmer, 15-32. New York: St. Martin's Press.

Strong, S. 1992. Shining Path: the world's deadliest revolutionary force. London: HarperCollins. Tarazona-Sevillano, G. 1990. Sendero Luminoso and the threat of narcoterrorism. New York: Praeger.

Taylor, L. 1987. Agrarian unrest and political conflict in Puno, 1985-1987. Bulletin of Latin American Research 6:135-162. 